\title{
Implementasi Pendidikan Akhlak Integratif-Inklusif
}

\author{
Muhammad Syafiqurrohman \\ Institut Agama Islam Negeri Purwokerto \\ syafiqurrohmanlu@gmail.com
}

Naskah diterima: 13 Januari 2020| Naskah disetujui: 20 Februari 2020

\begin{abstract}
Integrative-inclusive moral education can be interpreted as a formulation of a broad and holistic moral education process. Moral education materials can work together with all subjects, school culture, extracurricular activities, and even with the community. It is said that the integrative scientific structure does not mean that the various sciences are merged into an identical form of science, but rather the character, style, and nature of the science are integrated in the unity of the spiritual material dimensions, revelation, secularl-religion, physical-spiritual, and the world hereafter. Integration requires the existence of a relationship or unification or synchronization or greet each other or alignment between each existing scientific fields. Each scientific field cannot stand alone, without greeting each other with other scientific fields. While inclusive education, is a matter relating to many aspects of human life based on the principles of equality, justice, and individual rights. So integrative-inclusive education means that an educational process must cover a broad and comprehensive scope. Integrative-inclusive moral education has a holistic scope.
\end{abstract}

Keywords: Moral education, integrative-inclusive

\begin{abstract}
Abstrak
Pendidikan akhlak integratif-inklusif dapat dimaknai sebagai suatu rumusan proses pendidikan akhlak yang dilakukan secara luas dan holistik. Materi pendidikan akhlak dapat bersinergi dengan seluruh mata pelajaran, budaya sekolah, kegiatan ekstrakurikuler, serta dengan komunitas. Dikatakan struktur keilmuan integratif bukan berarti antara berbagai ilmu tersebut dilebur menjadi satu bentuk ilmu yang identik, melainkan karakter, corak, dan hakikat antara ilmu tersebut terpadu dalam kesatuan dimensi material spiritual, akal-wahyu, ilmu umum-ilmu agama, jasmani-rohani, dan dunia akhirat. Integrasi menghendaki adanya hubungan atau penyatuan atau sinkronisasi atau saling menyapa atau kesejajaran antar tiap bidang keilmuan yang ada. Setiap bidang keilmuan tidak dapat berdiri sendiri, tanpa saling menyapa dengan bidang keilmuan yang lain. Sedangkan pendidikan inklusif, merupakan suatu hal yang berkaitan dengan banyak aspek hidup manusia yang didasarkan atas prinsip persamaan, keadilan, dan hak individu. Maka pendidikan integratif-inklusif memiliki makna bahwa suatu proses pendidikan harus mencakup ruang lingkup yang luas dan menyeluruh. Pendidikan akhlak secara integratif-inklusif memiliki cakupan yang menyeluruh dan holistik.
\end{abstract}

Kata Kunci: Pendidikan akhlak, integratif-inklusif 


\section{Pendahuluan}

Fenomena pendidikan nasional yang selama ini hanya mengakomodasi pendidikan akhlak dalam pendidikan agama Islam menjadikan kajian materi yang bersikap menyendiri dan kurang berinteraksi dengan kegiatan-kegiatan pendidikan lainnya. Sebagai dampaknya, upaya realisasi nilai-nilai akhlak luhur pada diri peserta didik sangat terbatas dan sempit. Dengan demikian, nampak bahwa sistem pendidikan nasional belum memberi pengaruh signifikan terhadap pembentukan akhlak peserta didik. Hal ini kemudian menjadikan tujuan pendidikan akhlak sebagai pembentuk manusia yang senantiasa mengingatkan diri kepada norma-norma dan nilai-nilai luhur semakin sulit tercapai dan memperoleh banyak hambatan.

Al-Qur'an sebagai kitab yang memberi petunjuk kepada umat manusia di dalamnya terdapat keterangan berkisar 1500 ayat yang berbicara tentang akhlak dua setengah kali lebih banyak dari ayat-ayat tentang hukum baik secara teoritis maupun praktis. Hal tersebut belum terhitung hadishadis Nabi, baik perkataan maupun perbuatan, yang memberikan pedoman tentang pentingnya akhlak yang mulia dalam seluruh aspek kehidupan. Karena sesungguhnya Islam sangat memperhatikan pendidikan akhlak dan menganggapnya sebagai suatu hal yang sangat penting dan istimewa.

Peran penting pendidikan akhlak adalah sebagai jati diri umat Islam yang memfokuskan pada tata cara berprilaku luhur, seharusnya dapat bersinergi dalam komponen pendidikan secara integratif dan inklusif. Menghilangkan sekat dikotomi antar mata pelajaran serta memperhatikan perbedaan individu terutama dalam hal kemampuan dan kecepatan belajar, hal demikian seharusnya menjadi ruh dalam rangkaian proses pendidikan akhlak, pada akhirnya tugas pendidikan akhlak dalam mengaktualisasikan akhlak luhur pada jiwa peserta didik dapat dilakukan secara holistik tanpa terbatasi oleh sekat mata pelajaran dan kondisi peserta didik.

Artikel ini akan mengkaji lebih dalam tentang konsep integrasi materi akhlak dalam mata pelajaran umum. Hal tersebut sebagai upaya menjadikan materi pendidikan akhlak sebagai materi pembelajaran yang dinamis dan holistik sehingga pokok kajian pendidikan akhlak dapat bersinergi dalam seluruh rangkaian pembelajaran.

\section{Pendidikan Akhlak}

Secara etimologi, akhlak berasal bahasa Arab yang merupakan bentuk jamak dari kata khuluq, yang berarti budi pekerti, tingkah laku, atau tabiat. Akhlak Berakar dari kata khalaqa yang berarti menciptakan. Seakar dengan kata khaliq (pencipta), makhluq (yang diciptakan) dan khalaq (penciptaan). Kesamaan akar kata tersebut mengisyaratkan bahwa dalam akhlak tercakup pengertian keterkaitannya antara tuhan dan makhluk. Maka akhlak dapat diartikan sebagai suatu tata aturan atau norma perilaku yang mengatur hubungan keterkaitan antar manusia, manusia dengan tuhan bahkan manusia dengan alam semesta (Ilyas, 2002:vii).

Adapun secara istilah, akhlak adalah sistem nilai yang mengatur pola sikap dan tindakan manusia di muka bumi ini. Sistem nilai yang dimaksud adalah ajaran Islam, dengan al-Qur'an dan sunnah rasul sebagai sumber nilainya dan ijtihad sebagai metode berfikir Islami. Pola sikap dan tindakan yang dimaksud mencakup pola-pola hubungan dengan Allah, sesama manusia (termasuk dirinya sendiri) dan dengan alam (Nurdin, dkk, 1995: 209). 
Kata akhlak juga didefinisikan oleh para ulama dan tokoh pendidikan dalam bentuk yang sangat beragam, di antaranya sebagai berikut: (Ilyas, 2002:1-2)

a. Imam Al-Ghazali mendefinisikan bahwa akhlak adalah,

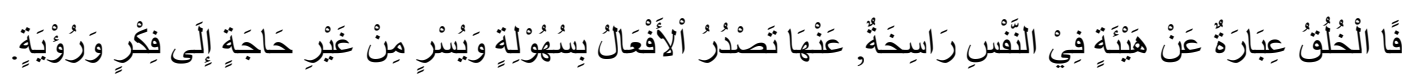

"Akhlak adalah sifat yang tertanam dalam jiwa yang menimbulkan perbuatan-perbuatan dengan gampang dan mudah, tanpa memerlukan pemikiran dan pertimbangan."

b. Ibrahim Anis mendefinisikan bahwa akhlak adalah,

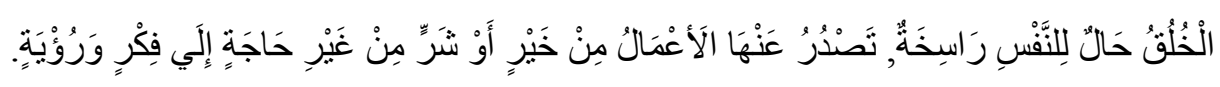

"Akhlak adalah sifat yang tertanam dalam jiwa, yang dengannya lahirlah macam-macam perbuatan, baik atau buruk, tanpa membutuhkan pemikiran dan pertimbangan.

c. Ibnu Maskawaih mendefinisikan bahwa akhlak adalah: (Djatnika, 1992:26-27)

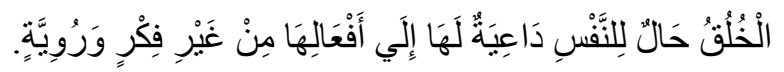

"Akhlak adalah keadaan gerak jiwa yang mendorong ke arah melakukaan perbuatan dengan tidak mengahajatkan pikiran.

d. Abdul Karim Zaidan

Akhlak adalah nilai-nilai dan sifat-sifat yang tertanam dalam jiwa, yang dengan sorotan dan timbangannya seseorang dapat menilai perbuatannya baik atau buruk, untuk kemudian memilih, melakukan dan meninggalkan. Definisi tersebut dapat dipahami bahwa akhlak adalah sifat yang tertanam dalam jiwa seseorang, yang mengakibatkan seseorang tersebut melakukan perbuatan baik atau buruk, dengan mudah tanpa adanya pemikiran panjang atau secara spontan, serta tidak memerlukan dorongan dari luar (Ilyas, 1992: 1-2).

\section{Pendidikan Akhlak Integratif-Inklusif}

Secara bahasa integratif berasal dari bahasa inggris yaitu integrate yang berarti penyatuan. Istilah ini pertama kali dikemukakan oleh John Dewey. Namun dengan gabungan kata lain seperti integrated curiculum approach, integrated teaching dan lain-lain, sedangkan secara istilah dapat diartikan sebagai suatu proses menjadikan satu (penyatuan). Integrasi dalam istilah psikologi yang diartikan sebagai sebuah proses penyatuan serangkaian peristiwa atau sistem-sistem yang berbeda menjadi suatu kebulatan yang sifatnya utuh atau sebuah upaya guna menghimpun suatu hubungan yang berarti atau relasi-relasi tertentu atau menunjuk pada adanya proses pengkoordinasian.

Secara umum integrasi diartikan sebagai penyatuan secara terencana dari bagian-bagian yang berbeda-beda menjadi satu kesatuan yang serasi. Menurut pandangan Assegaf, integratif pada 
mata pelajaran pendidikan agama Islam memiliki makna bahwa keterpaduan kebenaran wahyu (burhan qauli) dengan bukti bukti yang ditemukan di alam semesta (burhan kauni). Keterpaduan yang dimaksud antara ayat Al-qur'an atau hadis dengan kejadian yang dialami secara rasional atau dalam kehidupan sehari-hari (Mutma'inah, 2017: 435).

Dikatakan struktur keilmuan integratif bukan berarti antara berbagai ilmu tersebut dilebur menjadi satu bentuk ilmu yang identik, melainkan karakter, corak, dan hakikat antara ilmu tersebut terpadu dalam kesatuan dimensi material spiritual, akal-wahyu, ilmu umum ilmu agama, jasmaniruhani, dan dunia akhirat. Sedangkan interkoneksitas adalah keterkaitan satu pengetahuan dengan pengetahuan yang lain akibat adanya hubungan yang saling mempengaruhi. Integrasi menghendaki adanya hubungan atau penyatuan atau sinkronisasi atau saling menyapa atau kesejajaran antar tiap bidang keilmuan yang ada. Setiap bidang keilmuan tidak dapat berdiri sendiri, tanpa saling menyapa dengan bidang keilmuan yang lain. Keadaan saling menyapa ini, dapat muncul secara induktif, integral (menyatu dalam bahasan), dapat juga dalam bahasan yang komprehensif (kelengkapan aspek tinjauannya), interdisipliner dalam artian dari berbagai tinjauan, holistik (tinjauan menyeluruh) dan tematik (pembahasan sesuai dengan tema) (Mutma'inah, 2017: 435).

Secara etimologis inklusif memiliki arti terhitung, global, menyeluruh, penuh, dan komprehensif. Kata inklusif berasal dari bentukan kata bahasa Inggris inclusive yang artinya termasuk di dalamnya, sedangkan secara istilah inklusif, merupakan suatu hal yang berkaitan dengan banyak aspek hidup manusia yang didasarkan atas prinsip persamaan, keadilan, dan hak individu. Dalam paradigma pendidikan inklusif peserta didik dilihat sebagai mahluk hidup yang sama tidak terbedakan oleh sekat dikotomi strata sosial, budaya, serta kemampuan daya fikir dan kemampuan anggota fisik.

Oleh sebab itu pendidikan integratif-inklusif memiliki makna bahwa suatu proses pendidikan harus mencangkup ruang lingkup yang luas dan menyeluruh. Pendidikan akhlak secara integratif-inklusif memiliki cakupan ruang lingkup yang menyeluruh dan holistik. Pendidikan akhlak tidak memisahkan diri dari mata pelajaran yang lain serta memperhatikan kemampuan peserta didik dalam melakukan proses pembelajaran.

\section{Implikasi Pendidikan Integrasi-Inklusif}

Pendidikan Integrasi-inklusif tersebut dapat berangkat dari rancangan skenario pembelajaran, pelaksanaan pembelajaran, hingga evaluasi pembelajaran. Pembelajaran dengan berwawasan keilmuan integratif, menjadikan proses pembelajaran yang disampaikan oleh guru maupun dosen terjaga keutuhannya, dan tidak saling memisahkan antara satu ilmu dengan ilmu yang lain. Pendidikan tidak lagi sekedar normatif tapi juga saintifik. Pemahaman yang ditimbulkan dari Pembelajaran integratif akan menggiring peserta didik pada belajar secara totalitas, dan menjadikan materi pendidikan sebagai bagian dari kehidupan nyata (real life) yang dibutuhkan oleh mereka (Mutma'inah, 2017:437).

Adapun proses pengintegrasian dapat dilakukan dengan model sebagai berikut:

a. Integrasi tingkat filosofis 
Tingkat filosofis dalam integrasi sains-sosial dalam pembelajaran PAI dimaksudkan bahwa setiap kajian harus diberi nilai fundamental dalam kaitannya dengan disiplin keilmuan lainnya dan dalam hubungannya dengan nilai-nilai humanistik. Seperti mengajar materi Akhlak, di samping makna fundamentalnya sebagai filosofi membangun hubungan antar manusia, alam, dan Tuhan dalam ajaran Islam, dalam pengajaran Akhlak harus juga ditanamkan pada peserta didik bahwa eksistensi Akhlak tidaklah berdiri sendiri, melainkan berkembang bersama disiplin keilmuan yang lainnya seperti falsafah, sosiolugi, psikologi, dan lain sebagainya.

b. Integrasi tingkat metode dan pendekatan riset

Metodologi yang dimaksud di sini adalah metodologi yang digunakan dalam pengembangan ilmu bersangkutan (PAI). Dalam pengertian yang lebih luas berupa pendekatan (approach). Misalkan dalam perkuliahan Ilmu Pendidikan Islam (IPI), metodologi dan pendekatan yang digunakan adalah pengalaman empiris mahasiswa selama studi dengan jalan mengamati kegiatan lembaga pendidikan Islam. Berbeda dengan mata kuliah Filsafat Pendidikan Islam (FPI) menerapkan pola berpikir deduktif, yang berangkat dari kebenaran yang ada dalam Islam, kemudian dilihat dari fenomena-fenomena yang ada dalam masyarakat. Juga pola berpikir induktif, artinya berbagai kasus-kasus pendidikan ditarik hubungannya dengan norma-norma yang ada di dalam Islam.

c. Integrasi tingkat materi

Tingkat materi merupakan suatu proses bagaimana mengintegrasikan nilai-nilai kebenaran universal umumnya dengan kajian keIslaman khusususnya ke dalam sains-sosial seperti fisika, kimia, biologi, sosiologi, antropologi, hukum, politik, ekonomi, pendidikan, dan sebagainya. Sebaliknya, mempertemukan ilmu-ilmu umum tersebut ke dalam kajian keIslaman, dengan jalan memadukannya melalui epistemologi dan aksiologi. Sebagai contoh, untuk mengajarkan tema akhlak perlu menyajikan buku-buku secara integratif dengan jalan mempertemukan berbagai teori yang ada dalam kajian keIslaman dengan teori-teori modern.

d. Integrasi tingkat strategi

Jika tingkat materi menunjukkan pada bahan yang sedianya akan disampaikan dalam proses pembelajaran, maka tingkat strategi merupakan tahapan pelaksanaan pembelajaran dengan menerapkan berbagai model dan metode pembelajaran. Pembelajaran dengan model active learning dengan turunan berbagai macam metode, teknik, dan taktik pembelajaran adalah perlu dipilih dan dipraktekkan oleh guru-dosen pada saat proses pembelajaran berlangsung. Jika guru atau dosen menghadapi keterbatasan dan kelemanahan dalam pelaksanaannya, maka dapat dibentuk team teaching dengan guru atau dosen lintas bidang keilmuan, agar terjadi pembelajaran integratif. Semakin banyak disiplin keilmuan yang diintegrasikan dalam suatu pembelajaran, semakin membutuhkan strategi pembelajaran yang bervariasi serta melibatkan banyak guru atau dosen untuk mengajar bidang ilmu yang dikaji.

e. Integrasi tingkat evaluasi

Tingkat evaluasi dilakukan setelah seluruh proses pembelajaran PAI selesai, agar diketahui berapa besar keberhasialan dan kegagalan, keunggulan dan kelemahan, serta bagian mana yang perlu remedial. Tingkat evaluasi tidak bias diabaikan kerena proses pembelajaran tidak dapat 
diketahui hasilnya tanpa evaluasi. Evaluasi pendidikan secara singkat dimaknai sebagai kegiatan menilai yang terjadi dalam proses pendidikan. Pembelajaran PAI pada akhirnya perlu dievaluasi untuk mengukur ketercapaian tujuan dari pembelajaran itu sendiri (Mutma'inah, 2017: 444).

Kelima tingkat integrasi tersebut harus dilakukan secara simultan dan sinergis agar tiap level juga mengalami keterpaduan. Pada prinsipnya dari penjabaran di atas, integrasi keilmuan dapat dan harus dilakukan pada semua pembelajaran universal, pembelajaran akhlak dikaitkan dengan sains-sosial atau sebaliknya pembelajaran sains-sosial yang berintegrasi dengan keilmuan Islam. Sehingga pada akhirnya dikotomi keilmuan yang cenderung dapat merusak keseimbangan peradaban bisa dihindarkan.

\section{Materi Akhlak Berwawasan Integratif-Inklusif}

Model pengintegrasian pendidikan akhlak pada tingkat materi sebagai suatu cara dalam melakukan proses pendidikan akhlak dengan tidak terbatasi oleh bidang studi pendidikan akan tetapi mencakup bidang studi secara keseluruhan, bahkan mencakup seluruh program pendidikan secara integratif. Hasil rumusan Kemendiknas dan Kemenag menyimpulkan bahwa pendidikan budi pekerti (akhlak) bukan merupakan mata pelajaran tersendiri (monolitik), tetapi merupakan program pendidikan terpadu yang memerlukan prilaku, keteladanan, pembiasaan, bimbingan dan penciptaan lingkungan moralitas yang kondusif.

Pendidikan akhlak dapat menjadi soft skill (dampak pengiring) bagi setiap mata pelajaran. Hal ini bisa dilakukan, antara lain dengan memasukkan character-based approach sebagai upaya membangun karakter peserta didik yang berbudi luhur secara bersama-sama. Inilah bentuk upaya mengupayakan proses pendidikan akhlak secara integratif yang menjadi bagian penting dari pengembangan kurikulum 2004 yang bercorak KBK (Kurikulum Berbasis Kompetensi) menjadi KTSP (Kurikulum Tingkat Satuan Pendidikan) pada 2006 dan menjadi tugas penting bagi sekolah atau Sekolah untuk melakukan improvisasi guna meningkatkan mutu pendidikan, terutama dalam menanamkan dan membentuk kebiasaan berakhlak mulia bagi peserta didik. Pada tahun 2013 disempurnakan dengan kurikulum yang mengintegrasikan pendidikan karakter dalam setiap mata pelajaran (Royani, 2015:152).

Integrasi pada tingkat materi merupakan suatu proses bagaimana mengintegrasikan nilainilai kebenaran universal umumnya dengan kajian keIslaman khsususnya ke dalam sains-sosial seperti fisika, kimia, biologi, sosiologi, antropologi, hukum, politik, ekonomi, pendidikan, dan sebagainya. Sebaliknya, mempertemukan ilmu-ilmu umum tersebut ke dalam kajian keIslaman, dengan jalan memadukannya melalui epistimologi dan aksiologi. Sebagai contoh, untuk mengajarkan tema akhlak perlu menyajikan buku-buku secara integratif dengan jalan mempertemukan berbagai teori yang ada dalam kajian keIslaman dengan teori-teori modern. Integrasi pada tingkat materi dapat dilakukan dengan salah satu dari beberapa pendekatan, intradisipliner, multidisipliner, interdisipliner, dan transdisipliner sebagai berikut:

a. Integrasi Intradisipliner yaitu mengintegrasikan kompetensi-kompetensi sikap, pengetahuan dan keterampilan menjadi satu kesatuan utuh pada setiap mata pelajaran. Pendekatan ini dilakukan dengan merumuskan keempat kelompok kompetensi dasar. 
b. Integrasi Multidisipliner dan Interdisipliner dilakukan dengan membuat berbagai mata pelajaran saling berkaitan satu sama lain agar saling memperkuat, menghindari tumpang tindih dan dapat menjaga keselarasan setiap mata pelajaran. Integrasi multidisipliner dilakukan tanpa menggabungkan kompetensi dasar setiap mata pelajaran, sedangkan integrasi interdisipliner dilakukan dengan menggabungkan kompetensi-kompetensi dasar dari beberapa mata pelajaran menjadi satu.

c. Integrasi Transdisipliner yaitu dengan mengaitkan berbagai mata pelajaran yang ada dengan permasalahan permasalahan yang dijumpai di sekitarnya, sehingga pembelajaran menjadi kontekstual (Mutma'inah, 2017: 438).

\section{Pembelajaran Materi Akhlak Berwawasan Integratif-Inklusif}

Abudin Nata menyebutkan ada tiga hal pokok yang dapat dipahami sebagai materi pendidikan akhlak, yaitu hal-hal yang wajib bagi kebutuhan manusia, hal-hal yang wajib bagi jiwa, dan hal-hal yang wajib bagi hubungan dengan sesama manusia (Nata, 2003:12). Muhammad Abdullah Darrraz dalam bukunya Nasharuddin "Akhlak: Ciri Manusia Paripura" membagi ruang lingkup akhlak kepada enam bagian sebagai berikut:

a. Ibadah atau Akhlak kepada diri sendiri (al-akhlak al-afrdiyah) terdiri dari: yang diperintahkan (al-Awamir), yang dilarang (an-nawhu) yang dibolehkan (al-mubahat) dan akhlaq dalam keadaan darurat (al-mukhalafah bi al-idhthirah).

Akhlak pribadi atau akhlak terhadap diri sendiri merupakan hal yang berkaitan pengendalian hawa nafsu, bagaimana disaat kita sendiri, tidak ada oang lain, tidak ada yang melihat kecuali hanya Allah SWT semata dan kita mampu mengendalikan diri kita untuk selalu takut kepadaNya dan terhindar dari sesuatu yang dilarang atau dibenci untuk dilakukan.

b. Akhlak bernegara (al-akhlak ad-daulah) terdiri dari, hubungan antara pemimpin dan rakyat dan hubungan dengan luar negri.

Maksudnya adalah dalam bernegara hendaknya saling memberikan keamanan dan kenyamanan serta saling menjaga perdamaian dunia.

c. Akhlak terhadap lingkungan

Maksudnya adalah sesuatu yang ada di sekitar kita termasuk tumbuhan, binatang dan makhluk yang bernyawa maupun benda-benda yang tidak bernyawa.

Dasar yang digunakan sebagai pedoman akhlak terhadap lingkungan adalah tugas kekhalifahannya di bumi yang mengandung arti pengayoman, pemeliharaan serta pembimbingan agar setiap makhluk mencapai tujuan penciptaannya (Shihab, 2000: 261-270).

d. Akhlak beragama (al-akhlak ad-diniyah) yaitu kewajiban terhadap Allah SWT.

Akhlak kepada Allah (khalik) dapat diartikan sebagai sikap atau perbuatan yang seharusnya dilakukan oleh manusia makhluk terhadap Allah SWT sebagai khalik. Banyak cara yang dapat dilakukan dalam berakhlak kepada Allah SWT seperti yang telah disebutkan dalam al-Quran sebagai berikut: 
1) Tidak menyekutukan-Nya (QS. Annisa: 116)

2) Bertaqwa kepada-Nya (QS. An-Nur: 35)

3) Mencintai-Nya (QS. An-Nahl: 72)

4) Ridha dan ikhlas terhadap segala keputusan-Nya (QS. Al-Baqarah: 222)

5) Bersyukur terhadap segala nikmat-Nya (QS. Al-Baqarah: 152)

Lebih dari itu bahwa titik tolak dari akhlak kepada Allah adalah pengakuan dan kesadaran bahwa tiada Tuhan selain Allah. Dari pengakuan inilah dilanjutkan dengan sikap ikhlas dan ridha, beribadah kepadaNya, mencintai-Nya, banyak memuji-Nya, bertawakal kepadaNya, dan sikap-sikap lainnya yang diakumulasikan ke dalam sikap Inna Lillahi Wa Inna Ilaihi Raji'un (Yusuf, 2003:178-180).

e. Akhlak bermasyarakat (al-akhlak ijtimaiyah) terdiri dari yang dilarang, yang diperintahkan dan kaedah-kaedah adab.

Salah satu bentuk akhlak dalam bermasyarakat adalah janganlah berlaku sombong dan angkuh, akan tetapi hadapilah dengan muka yang berseri dan gembira, tanpa rasa sombong, dan tinggi diri.

f. Akhlak kepada keluarga (Birrul Waa Lidain) terdiri dari kewajiban tinggal, baik orang tua dan anak, kewajiban suami istri, dan kewajiban terhadap karib kerabat.

Akhlak berkeluarga termasuk salah satu bagian dari akhlak yang penting dalam kehidupan mengingat kita adalah makhluk sosial, bagaimana kita mempunyai kewajiban terhadap keluarga untuk memberi nafkah lahir batin, sandang pangan dan papan dengan tidak melalaikan kewajiban-kewajiban tersebut. Sistematika ruang lingkup akhlak di atas yang dirumuskan oleh Abu Draz menunjukkan bahwa ruang lingkup akhlak sangat luas mencangkup seluruh aspek kehidupan, baik secara vertikal maupaun horizintal. Dari sistematika tersebut dapat dipahami bahwa ruang lingkup akhlak meliputi, akhlak terhadap Allah SWT, akhlak pribadi, dalam keluarga, akhlak bernegara, akhlak terhadap lingkungan, akhlak beragama, serta akhlak bermasyarakat (Ilyas, 2002: 6).

Berdasarkan keterangan di atas dapat dipahami bahwa pendidikan akhlak merupakan suatu rangkaian proses pengintegrasian nilai-nilai kepribadian luhur terhadap peserta didik. Sebagai bekal kemampuan peserta didik dalam menempuh kehidupan sosial yang baik dan bermoral. Pendidikan akhlak mempunyai urgensi yang sangat asasi dalam kesejahteraan kehidupan di dunia dan di akhirat. Pendidikan akhlak mempunyai peran vital untuk membangkitkan masyarakat dari kebobrokan tingkah laku menuju masyarakat islami. Bahkan hampir semua permasalahan kehidupan yang muncul di tengah-tengah masyarakat bersumber dari minimnya akhlak.

Salah satu materi pembelajaran tentang akhlak adalah birrul waalidain atau bakti kepada orang tua, materi birrul waalidain hanya dapat direalisasikan dengan memenuhi tiga bentuk kewajiban yaitu, mentaati segala perintah orang tua, kecuali maksiat, menjaga amanah harta yang dititipkan orang tua, atau diberikan oleh orang tua dan membantu atau menolong orang tua bila mereka membutuhkan. Materi pendidikan akhlak dengan menggunakan pendekatan Integrasi 
transdisipliner pada materi akhlak Biruul walidain dapat diintegrasikan dalam berbagai materi pendidikan sebagai berikut:

a) Kisah Uwais Al Qorni

Merupakan kisah seorang pemuda dari Yaman pada masa Nabi yang sangat berbakti terhadap orang tuanya. Suatu ketia dia meminta izin kepada ibunya untuk bertemu Nabi, namun dia tidak dapat bertemu karena Nabi sedang melaksanakan perang dan dia tidak bisa menunggu Nabi karena tidak bisa meninggalkan ibunya yang sedang sakit. Sampai pada suatu ketika Nabi menceritakan pada para sahabat bahwa dia penghuni langit. Suatu ketika di saat dia meninggal terjadi hal yang luar biasa bahwa pada saat dimandikan, dikubur, dan jenazah dimakamkan sudah banyak orang yang melaksanankannya, yang menjadikan rasa takjub orang-orang Yaman.

b) Hadis Keutamaan Orang Tua

"Dari Aisah r.a ia berkata, " Pernah ada seorang laki-laki datang menemui Rasulallah saw. Bersama orang tua, Nabi bertanya, "siapakah orang yang mengertaimu itu?" Ayahku, jawabnya. Rasulallah berpesan kepadaya, jangan kau berjalan di depannya, jangan kau duduk sebelum dia duduk, jangan kau panggil dengan namanya, dan jangan kau memancing amarahnya." (HR. Ath-Thabari).

"Dari Aisah r.a ia berkata, " Pernah ada seorang laki-laki datang menemui Rasulallah saw. Bersama orang tua, Nabi bertanya, "siapakah orang yang mengertaimu itu?" Ayahku, jawabnya. Rasulallah berpesan kepadaya, jangan kau berjalan di depannya, jangan kau duduk sebelum dia duduk, jangan kau panggil dengan namanya, dan jangan kau memancing amarahnya." (HR. Ath-Thabari).

c) Peran Orang Tua dalam Proses Kejadian Manusia

Bahwa kedua orangtua memiliki peran yang sangat besar pada kehidupan kita mereka berkontribusi sebagai seseorang yang dititipi oleh Allah secara biologis memiliki andil dalam terciptanya kita. Sebagaimana Q.S Al-Mu'min Ayat 67 sebagai berikut;

Dia-lah yang mencipatakan kamu dari tanah kemudian dari setetes mani, sesudahnya itu dari segumpal darah kemudian dilahirkan kau sebgai seorang anak, kemudian (kamu dibiarakan hidup) supaya kamu sapai kepada masa (dewasa), Kemudian (dibiarkan kamu hidup lagi) sapai tua, diantara kamu ada yang diwafatkan sebelum itu. (kamiperbuat demikian) supaya kamu sapai kepada ajal yang ditentukan dan sepaya kamu memahami (Nya).

d) Dilapangkan Rezeki dan Umur Panjang

Sebuah hadis mengatakan bahwa keridhaan Allah terletak pada ridho orang tua, terdapat keterkaitan antara hubungan hablum minalloh dan hablum minnanas. Bentuk keterikatan itu adalah bahwa kebaikan yang kita berikan kepada orang tua akan berdampak pada diri kita begitu juga keburukannya. Maka dalam hadis lain juga dijelaskan bahwa birrul walidain akan memudahkan jalan rezeki dan umur panjang. Di antaranya rezeki sangat dipengaruhi kebaikan lewat orang di sekitar kita dan umur, kebahagiaan, cara hidup sehat, dapat juga demikian serta pemberian langsung. 


\section{Hakikat Pendidikan Akhlak Berwawasan Integratif-Inklusif}

Pendidikan akhlak integratif tidak cukup hanya dengan meletakkan dasar kebaikan perilaku dalam seluruh bidang studi dan menjadikannya sebagai satu kesatuan sistematis dalam membangun karakter peserta didik. Tidak cukup pula menciptakan lingkungan yang dapat menumbuhkan budi pekerti luhur hanya di sekolah, tetapi juga harus menciptakan lingkungan akhlak mulia ini terutama di lingkungan keluarga dan masyarakat, sehingga pendidikan akhlak integratif yang melibatkan semua pihak menjadi tanggungjawab bersama antara sekolah, keluarga dan masyarakat. Berikut skema pembelajaran pendidikan akhlak aplikatif intergratif merupakan model pendidikan ahlak yang terintegrasi ke dalam seluruh rangkian proses pendidikan akhlak, di mana dalam hal ini pendidik dianjurkan untuk menanamkan nilai pendidikan akhlak/ moral kepada siswa.

Skema 1. Pembelajaran Pendidikan Akhlak Aplikatif Intergratif

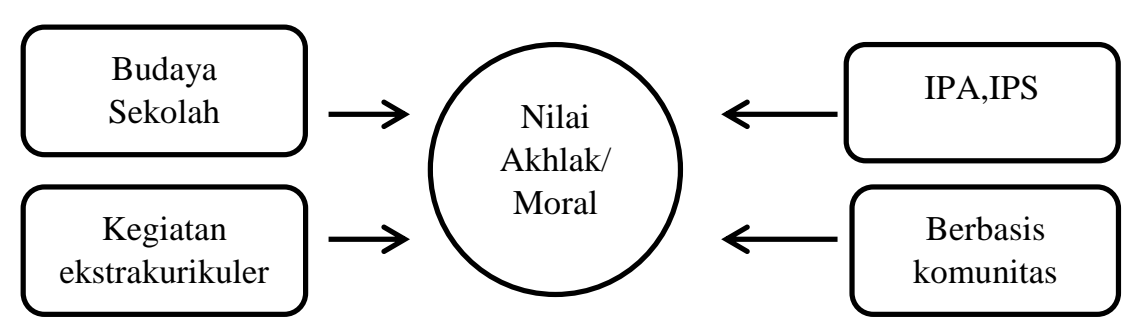

Amirulloh Syarbini dalam bukunya yang berjudul "Pendidikan Karakter: Panduan Lengkap Mendidik Karakter Anak di Sekolah dan di Rumah" membagi desain pendidikan akhlak/ pengembangan karakter di sekolah menjadi empat desain di antaranya yaitu:

Pertama, mengintegrasikan ke setiap mata pelajaran. Mengintegrasikan ke setiap mata pelajaran tujuan untuk memperkenalkan nilai-nilai akhlak disetiap mata pelajaran, sehingga menyadari akan pentingnya nilai tersebut. Nilai-nilai tersebut dicantumkan dalam silabus dan RPP. Pengembangan nilai-nilai itu dalam silabus ditempuh melalui cara-cara berikut ini:

a. Mengkaji Standar Komptensi (SK) dan Kompetensi Dasar (KD) pada Standar Isi (SI) untuk menentukan apakah nilai-nilai akhlak sudah tercakup di dalamnya

b. Menggunakan yang memperlihatkan keterkaitan antara SK dan KD dengan nilai dan indikator untuk menentukan nilai yang akan dikembangkan

c. Mencantumkan nilai-nilai akhlak dalam silabus

d. Mencantumkan nilai-nilai yang sudah tertera dalam silabus ke dalam RPP

e. Mengembangkan proses pembelajaran peserta didik secara aktif yang memungkinkan peserta didik memiliki kesempatan melakukan internalisasi nilai dan menunjukkannya dalam perilaku yang sesuai dan memberikan bantuan kepada peserta didik, baik yang mengalami kesulitan untuk menginternalisasi nilai maupun untuk menunjukkannya dalam perilaku. 
Kedua, pengembangan budaya sekolah, maksudnya yang membentuk akhlak siswa adalah pranata sosial sekolah kerena merekalah yang lebih tahu nilai-nilai apa yang harus dimiliki oleh peserta didik agar menjadi manusia yang berakhlak. Budaya sekolah cakupannya sangat luas, umumnya mencakup ritual, harapan, hubungan, demografi, kegiatan kurikuler, kegiatan ekstrakurikuler, proses mengambil keputusan, kebijakan maupun interaksi sosial antarkomponen di sekolah. Budaya sekolah adalah suasana kehidupan sekolah tempat peserta didik berinteraksi dengan sesamanya, pendidik dengan pendidik, konselor dengan sesamanya, pegawai administrasi dengan sesamanya, dan antar anggota kelompok masyarakat sekolah.

Interaksi internal kelompok dan antar kelompok terikat oleh berbagai aturan, norma, moral serta etika bersama yang berlaku di suatu sekolah. Kepemimpinan, keteladanan, keramahan, toleransi, kerja keras, disiplin, kepedulian sosial, kepedulian lingkungan, rasa kebangsaan, dan tanggung jawab merupakan nilai-nilai yang dikembangkan dalam budaya sekolah. Pengembangan nilai-nilai dalam pendidikan budaya dan karakter bangsa dalam budaya sekolah mencakup kegiatankegiatan yang dilakukan kepala sekolah, pendidik, konselor, dan tenaga administrasi ketika berkomunikasi dengan peserta didik dan menggunakan fasilitas sekolah.

Ketiga, melalui kegiatan ekstrakurikuler, kegiatan ekstrakurikuler merupakan kegiatan sekolah yang ada di luar jam pelajaran yang bertujuan untuk membentuk kreativitas siswa untuk bisa menyalurkan bakat, minat dalam rangka mendukung kemandirian siswa.

Keempat, desain berbasis komunitas dimana sekolah melibatkan orang tua dan masyarakat dalam membentuk akhlak peserta didik. Ki Hajar Dewantara menyebutkan pola kerjasama antara keluarga, masyarakat, dan sekolah (tripusat pendidikan) dalam membentuk budi pekerti sangat dibutuhkan oleh karena itu peran ketiganya tidak bisa dipisahkan (Purnama, 2019: 11). Pendidikan memiliki peranan yang sangat besar dalam membentuk kepribadian setiap manusia. Pendidikan merupakan proses pengembangan potensi peserta didik sehingga menjadi pribadi yang paripurna (insan kamil).

Salah satu indikator insan kamil tersebut adalah setiap peserta didik melahirkan akhlaq alkarimah. Sebagaimana yang dikemukakan oleh Ki Hajar Dewantara, bahwa ada tiga lembaga pendidikan yang turut berperan dalam mengembangkan potensi tersebut, yaitu pendidikan formal, informal dan non formal. Pendidikan formal diwakili oleh sekolah, pendidikan informal diwakili oleh keluarga dan pendidikan non formal dilakukan oleh masyarakat (Royani, 2015:154).

Intinya orangtua atau wali murid dan masyarakat, hendaknya memberikan contoh yang baik sesuai tuntunan al-Qur'an dan Hadist dalam kehidupan sehari-hari. Harapannya, peserta didik nantinya memiliki kecerdasan intelektual yang terbukti dengan prestasi akademik nasional dan internasional, emosional dan spiritual (Purnama, 2019: 12).

Dengan demikian proses pendidikan akhlak secara integratif-inklusif tidak selesai hanya pada batas mata pelajaran di sekolah namun seluruh rangkain proses pendidikan formal, nonformal serta informal turut serta melaksanaakan perannya sebagai lingkungan yang sangat berpengaruh dalam mengembangkan kemampuan kognitif, afektif dan psikomotorik peserta didik. 


\section{Kesimpulan}

Pendidikan akhlak berwawasan integratif-inklusif dapat dimaknai sebagai suatu rumusan proses pendidikan akhlak yang dilakukan secara luas dan holistik. Materi pendidikan akhlak dapat bersinergi dengan seluruh mata pelajaran, dapat bersinergi dengan budaya sekolah, kegiatan ekstrakurikuler serta bersinergi dengan komunitas.

Pertama, mengintegrasikan ke setiap mata pelajaran bertujuan untuk memperkenalkan nilainilai akhlak di setiap mata pelajaran, sehingga menyadari akan pentingnya nilai tersebut. Nilai-nilai tersebut dicantumkan dalam silabus dan RPP. Integrasi pada tingkat materi ini dapat dilakukan melalui empat pendekatan yaitu, pendekatan intradisipliner, multidisipliner, interdisipliner, dan transdisipliner.

Kedua, pengembangan budaya sekolah maksudnya yang membentuk akhlak siswa adalah pranata sosial sekolah kerena merekalah yang lebih tahu nilai-nilai apa yang harus dimiliki oleh peserta didik agar menjadi manusia yang berakhlak. Budaya sekolah cakupannya sangat luas, umumnya mencakup ritual, harapan, hubungan, demografi, kegiatan kurikuler, kegiatan ekstrakurikuler, proses mengambil keputusan, kebijakan maupun interaksi sosial antarkomponen di sekolah.

Ketiga, melalui kegiatan ekstrakurikuler, kegiatan ekstrakurikuler merupakan kegiatan sekolah yang ada di luar mata pelajaran yang bertujuan untuk membentuk kreativitas siswa untuk bisa menyalurkan bakat, minat dalam rangka mendukung kemandirian siswa.

Keempat, desain berbasis komunitas dimana sekolah melibatkan orang tua dan masayarakat dalam membentuk akhlak peserta didik menjadi pribadi yang paripurna (insan kamil).

\section{Daftar Pustaka}

Djatnika, R. (1992). Sistem Ethika Islami, Jakarta: Pustaka Panjimas.

Ilyas, Y. (2002). Kuliah Akhlaq, Yogyakarta: Lembaga Pengkajian Dan Pengalaman Islam.

Mutma'inah, S. (2017). Pendekatan Integratif: Tinjauan Paradigmatif dan Implementatif dalam Pembelajaran Fikih di Madrasah Ibtidaiyah. Jurnal Elementari Vol. 5 / No. 2.

Nata, A. (2002). Pemikiran Para Tokoh Pendidikan Islam, Jakarta: PT. Grafindo Persada.

Nurdin, M. dkk. (1995). Moral dan Kognisi Islam, Bandung: CV Alfabeta.

Purnama, M. (2019). Implementasi Pendidikan Agama Islam yang Integratif (Antara Guru, Orang Tua, dan Masyarakat). QALAMUNA: Jurnal Pendidikan, Sosial, Dan Agama, 11(2), 141156. https://doi.org/10.5281/zenodo.3559273

Royani, A. (2015). Pendidikan Akhlak Aplikatif Integratif Di Sekolah. Jurnal Fenomena, Vol. 14. Shihab, M. (2000). Wawasan al-Qur'an, Bandung: Mizan.

Yusuf, A. (2003). Studi Agama Islam Untuk Perguruan Tinggi Umum. Bandung: Pustaka Setia. 